\title{
Social capital associated with quality of life among late adults and elderly population in the Northeast of Thailand [version 1; peer review: 2 approved with reservations]
}

\author{
Kitti Prachuntasen 1 , Wongsa Laohasiriwong (iD)1,2, Amornrat Luenam³ \\ ${ }^{1}$ Faculty of Public Health, Khon Kaen University, Khon Kaen, Thailand \\ ${ }^{2}$ Training Center for Enhancing Quality of Life for Working Age People, Khon Kaen University, Khon Kaen, Thailand \\ ${ }^{3}$ Faculty of Public and Environmental Health, Huachiew Chalermprakiet University, Samut Prakan, Thailand
}

\author{
V1 First published: $26 \mathrm{Apr}$ 2018, 7:496 \\ https://doi.org/10.12688/f1000research.13954.1 \\ Latest published: 26 Apr 2018, 7:496 \\ https://doi.org/10.12688/f1000research.13954.1
}

\begin{abstract}
Background: Previous studies indicated that social capital (SC) has an influence on quality of life (QOL). However, there are limited studies on how SC might associate with QOL among late adults and elderly in Thailand.
\end{abstract}

Methods: This cross-sectional study was conducted among 1,148 participants who were identified by multistage random sampling from 4 provinces in the Northeast of Thailand. A self - administered questionnaire was developed and used to assess cognitive social capital (CSC), structural social capital (SSC), accessibility to health services, and socioeconomic status (SES) and QOL. The Generalized Linear Mixed Model (GLMM) was used to determine the association between SC and QOL when controlling for other covariates.

Results: Only $41.03 \%$ (95\%CI: 38.17 to 43.94 ) of the participants had good QOL. About half (50.26\%) had high level of CSC, whereas only $36.15 \%$ had high level of SSC. The multivariate analysis indicated that having high levels of CSC and SSC was associated with good QOL. Other factors that were associated with having good QOL were aged $<60$ years old, monthly income $\geq 15,000$ baht, adequate income, adequate physical activity, lived in the municipality, and had high level of accessibility to health services.

Conclusion: Less than half of late adults and elderly had good QOL and high level of SSC. About half had high level of CSC. Both CSC and SSC had influence on QOL as well as gender, age, monthly income, financial status, physical activity, residential area, and accessibility to health services.

Keywords

Social Capital, Quality of Life, Late Adults and Elderly Population, Thailand

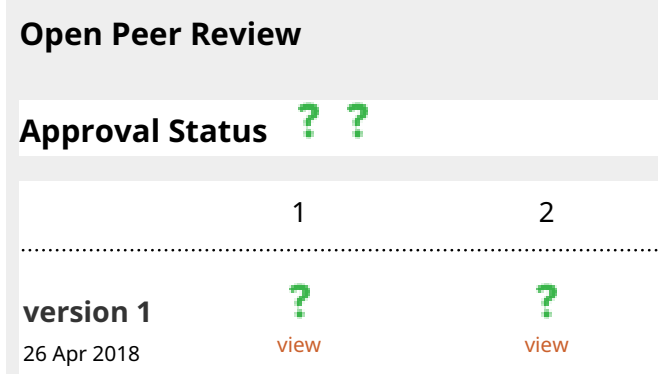

1. Farid Najafi, Kermanshah University of Medical Sciences, Kermanshah, Iran

2. Agnes Iok Fong Lam ID, University of Macau, Macau, China

Any reports and responses or comments on the article can be found at the end of the article. 
Corresponding author: Wongsa Laohasiriwong (drwongsa@gmail.com)

Author roles: Prachuntasen K: Conceptualization, Data Curation, Investigation, Writing - Original Draft Preparation, Writing - Review \& Editing; Laohasiriwong W: Methodology, Supervision, Validation; Luenam A: Conceptualization, Data Curation, Investigation, Writing Original Draft Preparation, Writing - Review \& Editing

Competing interests: No competing interests were disclosed.

Grant information: This research was financially supported by the Research and Training Center for Enhancing Quality of Life for Working Age People, Khon Kaen University, Thailand.

The funders had no role in study design, data collection and analysis, decision to publish, or preparation of the manuscript.

Copyright: $\odot 2018$ Prachuntasen $\mathrm{K}$ et al. This is an open access article distributed under the terms of the Creative Commons Attribution License, which permits unrestricted use, distribution, and reproduction in any medium, provided the original work is properly cited. Data associated with the article are available under the terms of the Creative Commons Zero "No rights reserved" data waiver (CC0 1.0 Public domain dedication).

How to cite this article: Prachuntasen K, Laohasiriwong W and Luenam A. Social capital associated with quality of life among late adults and elderly population in the Northeast of Thailand [version 1; peer review: 2 approved with reservations] F1000Research 2018, 7:496 https://doi.org/10.12688/f1000research.13954.1

First published: 26 Apr 2018, 7:496 https://doi.org/10.12688/f1000research.13954.1 


\section{Introduction}

Quality of life (QOL) is the extent to which personal perception on comfortable or satisfying of their life in relation to their objectives, expectancy, standards, and concerns. It involves health and happiness, rather than wealth ${ }^{1,2}$. It includes all interpersonal and social capital (SC) ${ }^{3}$.

SC is considered an important imperceptible health resource 4 . With growing recognition of the socioeconomic status (SES), and the social determinants of health, SC is now considered more significant to building healthcare systems ${ }^{5-7}$. SC has been described as a feature of social organization, for instance, norms, reliance and networks that can enhance the performance of community by accommodate coordinated actions ${ }^{8}$. The measuring of SC can maybe provision worthy insights into social networks and also connections that persons and communities have and more importantly, how these networks and connections possible have been utilized to encourage the positive outcomes for the person and the community. In this manner, the measuring of SC might augment our understanding of how persons in the community can work cooperatively to manage their problems and to accomplish their common goals. In addition, previous studies indicated that SC was associated with QOL. Particularly Majid Karimzadeh et al. (2013) ${ }^{9}$ indicated that SC is considered as a significant determinant of QOL. This SC is the sum of the actual or potential resources which are linked to a durable network of institutionalized relationships of generalized trustworthiness and active involvement that lead to mutual acquaintance or recognition, which are made up of social obligations or connections. The SC could convertible into economic capital and may be institutionalized in the form of a title of nobility ${ }^{10}$. Accessibility to health services can be highly influential on QOL and is related to both health care utilization and health outcomes such as stage at diagnosis and mortality ${ }^{11}$.

The Northeast of Thailand, the biggest region both in terms of areas and containing one- third of Thailand's 68 million populations. It is the poorest region in the country. Many of Northeastern migrate to work in other regions and overseas. Many of them usually leave family members include elderly at home. This socioeconomic situation might impact people way of life and their SC. The SC is importance in the culture in which they live. The National Bureau of Statistics indicated that SC matters definitely generate impact on QOL in the Northeast of Thailand, demonstrating results that will be applicable to other developing countries in the future.

There have been limited studies on SC among the Northeasterners and its association with QOL. Hence, the aims of this study were to investigate the prevalence and association between the SC and QOL in the Northeast of Thailand. The evidence from this study could be used as inputs for relevant sectors to develop measures in order to improve health and reduce inequalities in health through healthy public policy and strengthening community actions.

\section{Methods}

This cross-sectional study was conducted during June 2016 to September 2017 in the 4 provinces of the Northeast region of Thailand include Loei, Khon Kean, Ubon Ratchathani and Nakhon Ratchasima provinces.

\section{Study participants}

The inclusion criteria for participants were those who aged 40 years old or more, have lived in the Northeast of Thailand, could verbally communicate with the researchers and agree to participate with written inform consent. The exclusion criteria were severe impairment and/or having mental illness which limited their communication with the researchers.

The multiple logistic regressions used to identify the associations between multiple independent variables and a dichotomous outcome of QOL being high ${ }^{12}$ was used to estimate the sample size. The approximate sample size was 218 . In order to control the over-fitting, we used $\rho$ and variance inflation factor $(\mathrm{VIF})^{13}$ which were 0.9 and 5.26 , respectively. Therefore, the total number of samples was 1,148 .

A multistage random sampling method was used to choose participants of 4 provinces in the Northeast of Thailand, include Loei, Khon Kean, Ubon Ratchathani and Nakhon Ratchasima provinces. Firstly 4 provinces were randomly selected, and then 2 districts of each province were randomly selected namely Wangsaphung, Chiang Khan, Ban Phai, Chum Phae, Mueang Ubon Ratchathani, Det Udom, Phimai, and Sikhio, respectively. Third, three sub-districts from each province were randomly selected namely Pha Bing, Pak Puan, Khok Khamin, That, Chiang Khan, Na Sao, Mueang Phia, Hin Tang, Ban Phai, Wang Hin Lat, Non Sa-at, Nong Phai, Pathum, Rai Noi, Nong Bo, Mueang Det, Som Sa-at, Kaeng, Rang Ka Yai, Nong Rawiang, Bot, Wang Hin Lat, Non Sa-at, Nong Phai, respectively. Therefore 24 sub-districts were included in the study. The fourth stage was random selection of a village in each the sub-district. Then simple random sampling was applied to select 1,148 individuals proportionate to the size of the population to be included in this study. All participants were interviewed face-to-face by trained interviewers. The interview were performed door to door.

\section{Research tools}

The research tool was a structured questionnaire which was developed from reviewing literature. The questionnaire underwent content validation by 3 experts and then it was revised to improve validity. The questionnaire was tested for reliability using Conbach alpha amongst 30 participants who had similar characteristics with the samples in Nakhon Phanom province. Its Conbach alpha coefficient was 0.96. The questionnaire consisted 
of four parts: (1) socioeconomic (2) social capital; (3) accessibility to health services; and (4) quality of life (Supplementary File 1).

\section{Assessment of quality of life}

QOL was assessed using the Quality of Life scale (WHOQOL - BREF) of WHO Thai short version ${ }^{14}$. It is consisted of 26 items within the 4 domains containing physical, psychological, social relationships and environment domains. The scores are categorized into 3 groups: poor level (26-60 scores), fair level (61-95 scores) and good level (96-130 scores). Since the multiple logistic regression analysis of Hsieh is for the dichotomous outcome $^{13}$. Therefore, in the bivariable and multivariable analysis we dichotomized the QOL as good QOL and poor/fair QOL, using cutoff point of below 96 for poor/fair QOL and 96 or above for good QOL ${ }^{15}$.

\section{Social capital measurement}

This study applied the concept of cognition and structure SC developed by Bain and Hicks in 1998. Six dimensions of cognition social capital (CSC) were examined in this study consisted of trust, solidarity, reciprocity, attitudes, behavior and social norms. Four dimensions of structure social capital (SSC) were included: horizontal organizational structure, accountability of leaders, collective/transparent decision-making process and practices of collective action and responsibility ${ }^{16}$. The response ranged from strongly disagree (1) to strongly agree (5). The SC scores are between 50 and 250. The higher scores reflected greater SC. Since the multiple logistic regression analysis of Hsieh is for the dichotomous outcome ${ }^{13}$. Therefore, in the bivariable and multivariable analysis the scores of cognitive social capital and structural social capital were dichotomized, using the mean as the cutoff point, as low/moderate ( $<3.68$ scores) and high $(\geq 3.68$ scores $)$,

\section{Accessibility measurement}

The concept of access to health services of Penschansky \& Thomas, $1981^{17}$ was utilized in this study. The accessibility to health services was determined in term of individual's satisfaction on health services covering the domains of accessibility, availability, affordability accommodation and acceptability. The scores ranged from strongly disagree to strongly agree (1 to 5 scores). The possible scores ranged 35-175. Higher scores mean higher accessibility. In the associations analysis the mean scores of accessibility to health services were dichotomized since the multiple logistic regression analysis of Hsieh is for the dichotomous outcome ${ }^{13}$, as low/ moderate ( $<3.68$ scores) and high ( $\geq 3.68$ scores).

\section{Socio-economic status (SES) and risk factors}

Socio-economic status in this study composed of gender, age, weight, high, educational attainment, marital status, occupation, monthly income, financial status, smoking, alcohol consumption, physical activity, residential area, and chronic diseases were treated as covariates in the analysis.

To minimized information bias, we trained interviewers and standardized the data collection competency in Loei, Khon Kean,
Ubon Ratchathani and Nakhon Ratchasima provinces at our interviewer training workshop organized in Khon Kaen province. After the participants understanding of the purpose of this study and then signed consent informs. They were structured questionnaire interviewed by well-trained and standardized interviewers.

\section{Data analysis}

STATA $^{\circledR}$ (ver. 13; College Station, TX, USA: Stata Corp). The categorical data were presents as frequency and percentage whereas the continuous data were explained their magnitude as mean, standard deviation, median, and range.

The GLMM was operated to model the random effects and correlations inside clusters ${ }^{18}$ since our study used multistage random sampling methods to choose the participants. In the modeling, the participant residential area was fixed whereas the aged was set as the random effect. Classification of QOL was done using univariable analysis, displayed as percentage of good QOL and its $95 \%$ confidence interval (CI).

Bivariable analysis was utilized to define the association of each independent variable with QOL. Any independent variables, in the bivariate analysis that had $\mathrm{p} \leq 0.25$ were chosen and continue to the multivariable analysis ${ }^{13}$.

In order to control the random effects and correlations inside clusters, the GLMM were operated before using multiple logistic regressions to determine the association between social capitals, residential area, accessibility to health services, gender, age, monthly income, financial status, and physical activity and QOL while controlling covariates (BMI, marital status, education, smoking, alcohol consumption, chronic disease, and occupation). The final model results presented the magnitude of association of independent variables and QOL were adjusted odds ratio (adjusted OR), and 95\% CI.

\section{Ethics statement}

This research proposal and tool got approval from the Khon Kaen University Ethics Committee in Human Research, the approval number, HE 602127). Written informed consent was gathered from all participants.

\section{Results}

The characteristics and SES of the participants are shown in Table 1. The majority of participants were female $(60.63 \%)$, married $(78.05 \%)$, completed elementary school $(58.01 \%)$, with the average age of $58.36 \pm 11.95$ years old, live in rural areas $(53.48 \%)$. As high as $41.81 \%$ had average monthly income $5,000-15,000,46.34 \%$ were unemployed, $47.3 \%$ had adequate income but not saving. Majority were overweight and obesity $54.35 \%$. Most of them did not drink alcohol (75.70\%), were not smoking $(81.71 \%)$, had adequate physical activity $(67.86 \%)$ Almost one third had chronic disease $(32.06 \%)$. About half of participants had high cognitive social capital (CSC) $(50.26 \%)$. Only $36.15 \%$ had high level of SSC. About one third (35.28\%) had low level of accessibility to health care services. 
Table 1. Characteristics of participants in the Northeast of Thailand $(n=1,148)$.

\begin{tabular}{|c|c|c|c|c|}
\hline \multicolumn{2}{|c|}{ Characteristics } & \multirow[t]{2}{*}{ Number } & \multirow[t]{2}{*}{ Percent } & \multirow[t]{2}{*}{$95 \% \mathrm{Cl}$} \\
\hline Gender & & & & \\
\hline & Female & 696 & 60.63 & 57.73-63.47 \\
\hline & Male & 452 & 39.37 & $36.53-42.27$ \\
\hline \multicolumn{5}{|c|}{ Age (years) } \\
\hline & $40-49$ & 334 & 29.09 & $26.48-31.82$ \\
\hline & $50-59$ & 298 & 25.96 & $23.44-28.60$ \\
\hline & $60-69$ & 293 & 25.52 & $25.52-28.15$ \\
\hline & $70-79$ & 168 & 14.63 & $12.64-16.81$ \\
\hline & $\geq 80$ & 55 & 4.79 & $3.63-6.19$ \\
\hline & Mean $\pm S D$ & \multicolumn{2}{|c|}{$58.36 \pm 11.95$} & \\
\hline & $\begin{array}{l}\text { Median } \\
\text { (Min:Max) }\end{array}$ & \multicolumn{2}{|c|}{$\begin{array}{c}57 \\
(40: 96)\end{array}$} & \\
\hline \multicolumn{5}{|l|}{ BMI } \\
\hline & Underweight & 67 & 5.84 & $4.55-7.35$ \\
\hline & Normal & 457 & 39.81 & $36.96-42.71$ \\
\hline & Overweight & 244 & 21.25 & 18.92-23.74 \\
\hline & Obese & 380 & 33.10 & $30.38-35.91$ \\
\hline & Mean \pm SD & \multicolumn{2}{|c|}{$23.64 \pm 3.81$} & \\
\hline & $\begin{array}{l}\text { Median } \\
\text { (Min:Max) }\end{array}$ & \multicolumn{2}{|c|}{$\begin{array}{c}23.44 \\
(13.15: 61.83)\end{array}$} & \\
\hline \multicolumn{5}{|c|}{ Marital status } \\
\hline & Single & 58 & 5.05 & $3.86-6.48$ \\
\hline & Married & 896 & 78.05 & $75.41-80.41$ \\
\hline & Windowed/Divorced/ Separated & 194 & 16.90 & $14.77-19.19$ \\
\hline \multicolumn{5}{|c|}{ Education } \\
\hline & Uneducated & 39 & 3.40 & $2.43-4.62$ \\
\hline & Elementary school & 666 & 58.01 & $55.10-60.89$ \\
\hline & Junior school & 82 & 7.14 & $5.72-8.79$ \\
\hline & Senior high school & 132 & 11.50 & $9.71-13.49$ \\
\hline & High or vocational Certificate & 59 & 5.14 & $3.94-6.58$ \\
\hline & Bachelor's degree or above & 170 & 14.81 & $12.80-16.70$ \\
\hline \multicolumn{5}{|c|}{ Monthly income (baht) } \\
\hline & $<5,000$ & 449 & 39.11 & $36.28-42.00$ \\
\hline & $5,000-15,000$ & 480 & 41.81 & $39.94-44.73$ \\
\hline & $15,001-25,000$ & 78 & 6.79 & $5.41-8.41$ \\
\hline & $25,001-35,000$ & 61 & 5.31 & $4.09-6.77$ \\
\hline & $35,001-45,000$ & 26 & 2.26 & $1.48-3.30$ \\
\hline & $>45,000$ & 54 & 4.70 & $3.55-6.09$ \\
\hline & Mean \pm SD & \multicolumn{2}{|c|}{$11,966.42 \pm 17,592.29$} & \\
\hline & $\begin{array}{l}\text { Median } \\
\text { (Min:Max) }\end{array}$ & \multicolumn{2}{|c|}{$\begin{array}{c}17,592.29 \\
(500: 190,000)\end{array}$} & \\
\hline
\end{tabular}




\begin{tabular}{|c|c|c|c|c|}
\hline \multicolumn{2}{|c|}{ Characteristics } & \multirow[t]{2}{*}{ Number } & \multirow[t]{2}{*}{ Percent } & \multirow[t]{2}{*}{$95 \% \mathrm{Cl}$} \\
\hline Occupation & & & & \\
\hline & Trade & 121 & 10.54 & $8.82-12.46$ \\
\hline & General hire & 148 & 12.89 & $11.01-14.97$ \\
\hline & Government servant & 159 & 13.85 & $11.90-15.98$ \\
\hline & Agriculture & 188 & 16.38 & $14.28-18.65$ \\
\hline & Unemployed & 532 & 46.34 & $43.43-49.28$ \\
\hline \multicolumn{5}{|c|}{ Financial status } \\
\hline & Adequate income with saving & 256 & 22.30 & $19.92-24.82$ \\
\hline & Adequate with no saving & 544 & 47.39 & $44.46-50.32$ \\
\hline & Inadequate & 348 & 30.31 & $27.66-33.06$ \\
\hline \multicolumn{5}{|l|}{ Smoking } \\
\hline & No & 938 & 81.71 & 73.11-78.15 \\
\hline & Yes & 210 & 18.29 & $16.10-20.65$ \\
\hline \multicolumn{5}{|c|}{ Alcohol Consumption } \\
\hline & No & 869 & 75.70 & $73.11-78.15$ \\
\hline & Yes & 279 & 24.30 & $21.85-26.89$ \\
\hline \multicolumn{5}{|c|}{ Physical activity } \\
\hline & Inadequate & 369 & 32.14 & $29.45-34.93$ \\
\hline & Adequate & 779 & 67.86 & $65.07-70.55$ \\
\hline \multicolumn{5}{|c|}{ Residential area } \\
\hline & Rural areas & 614 & 53.48 & $50.55-56.40$ \\
\hline & Sub-district municipality & 407 & 35.46 & $32.68-38.30$ \\
\hline & Town Municipality & 127 & 11.06 & $9.31-13.02$ \\
\hline \multicolumn{5}{|c|}{ Chronic diseases } \\
\hline & Yes & 368 & 32.06 & $29.36-34.84$ \\
\hline & No & 780 & 67.94 & $65.16-70.64$ \\
\hline \multicolumn{5}{|c|}{$\begin{array}{l}\text { Cognitive social } \\
\text { capital }\end{array}$} \\
\hline & Low & 17 & 1.48 & $0.09-2.36$ \\
\hline & Moderate & 554 & 48.26 & $45.33-51.19$ \\
\hline & High & 577 & 50.26 & $47.33-53.19$ \\
\hline \multicolumn{5}{|c|}{$\begin{array}{l}\text { Structural social } \\
\text { capital }\end{array}$} \\
\hline & Low & 29 & 2.53 & $16.98-36.08$ \\
\hline & Moderate & 704 & 61.32 & $58.44-64.15$ \\
\hline & High & 415 & 36.15 & 33.37-39.01 \\
\hline \multicolumn{5}{|c|}{$\begin{array}{l}\text { Accessibility to } \\
\text { health care services }\end{array}$} \\
\hline & Low & 405 & 35.28 & $32.51-38.12$ \\
\hline & Moderate & 412 & 35.89 & $33.11-38.74$ \\
\hline & High & 331 & 28.83 & $26.23-31.55$ \\
\hline
\end{tabular}


Most of the participant (58.19\%) had fair level of QOL followed by good $(41.03 \%)$ and poor levels $(0.78 \%)$ (Table 2$)$.

Crude odds ratio obtained from performing bivariate analysis of each factor and QOL

The bivariate analysis revealed that both cognitive and structural social capital had influences on QOL. Other factors including gender, age, education, marital status, education, monthly income, occupation, financial status, physical activity, residential area, and accessibility to health care services also associated with QOL. The factors with $\mathrm{p}<0.25$ in the bivariable analysis were proceed to the multivariate analysis (Table 3 ).

Multivariable analysis for associated factors of QOL

MGLMM was performed to control the clustering effect of the sampling method in selecting the participants. The association between multiple independent variables and QOL was determine using multivariate analysis to control the effect of covariates.

\begin{tabular}{|c|c|c|c|}
\hline QOL & $\mathbf{n}$ & percent & $95 \% \mathrm{Cl}$ \\
\hline Poor level (26-60 scores) & 9 & 0.78 & $0.36-1.48$ \\
\hline Fair level (61-95 scores) & 668 & 58.19 & $55.27-61.06$ \\
\hline Good level (96-130 scores) & 471 & 41.03 & $38.17-43.94$ \\
\hline
\end{tabular}

Table 3. Crude odds ratio obtained from performing bivariate analysis of each factor and quality of life $(Q O L)(n=1,148)$.

\begin{tabular}{|c|c|c|c|c|c|c|}
\hline \multicolumn{2}{|c|}{ Characteristics } & \multirow{2}{*}{$\begin{array}{l}\% \mathbf{N} \\
1,148\end{array}$} & \multirow{2}{*}{$\begin{array}{c}\% \text { Good } \\
\text { QOL } \\
41.03\end{array}$} & \multirow[t]{2}{*}{ OR } & \multirow{2}{*}{$\begin{array}{c}95 \% \mathrm{Cl} \\
38.17 \text { to } 43.94\end{array}$} & \multirow[t]{2}{*}{ P-value } \\
\hline Overall & & & & & & \\
\hline \multirow{3}{*}{$\begin{array}{l}\text { Cognitive social } \\
\text { capital }\end{array}$} & & & & & & $<0.001$ \\
\hline & Low/Moderate & 571 & 23.12 & 1 & - & \\
\hline & High & 577 & 58.75 & 5.30 & 4.01 to 7.00 & \\
\hline \multirow{3}{*}{$\begin{array}{l}\text { Structural social } \\
\text { capital }\end{array}$} & & & & & & $<0.001$ \\
\hline & Low/Moderate & 733 & 29.33 & 1 & - & \\
\hline & High & 415 & 61.69 & 4.83 & 3.63 to 6.42 & \\
\hline \multirow{3}{*}{$\begin{array}{l}\text { Accessibility to } \\
\text { health care services }\end{array}$} & & & & & & $<0.001$ \\
\hline & Low/Moderate & 817 & 34.15 & 1 & - & \\
\hline & High & 331 & 58.01 & 2.81 & 2.11 to 3.73 & \\
\hline \multirow[t]{3}{*}{ Residential area } & & & & & & $<0.001$ \\
\hline & $\begin{array}{r}\text { Rural, Sub-district } \\
\text { municipality }\end{array}$ & 1,021 & 36.92 & 1 & - & \\
\hline & Town Municipality & 127 & 74.02 & 5.43 & 2.53 to 11.64 & \\
\hline \multirow[t]{3}{*}{ Gender } & & & & & & 0.005 \\
\hline & Female & 696 & 38.36 & 1 & - & \\
\hline & Male & 452 & 45.13 & 1.45 & 1.11 to 1.88 & \\
\hline \multirow[t]{3}{*}{ Age (years) } & & & & & & $<0.001$ \\
\hline & $\geq 60$ & 516 & 29.84 & 1 & - & \\
\hline & $<60$ & 632 & 50.16 & 2.37 & 1.57 to 3.57 & \\
\hline BMI & & & & & & 0.914 \\
\hline
\end{tabular}




\begin{tabular}{|c|c|c|c|c|c|c|}
\hline \multicolumn{2}{|c|}{ Characteristics } & \multirow{2}{*}{$\begin{array}{l}\% \mathbf{N} \\
624\end{array}$} & \multirow{2}{*}{$\begin{array}{c}\% \text { Good } \\
\text { QOL } \\
41.03\end{array}$} & \multirow{2}{*}{$\begin{array}{c}\text { OR } \\
1\end{array}$} & \multirow{2}{*}{$\begin{array}{c}95 \% \mathrm{Cl} \\
-\end{array}$} & \multirow[t]{2}{*}{ P-value } \\
\hline & Overweight/obese & & & & & \\
\hline & Normal/underweight & 524 & 41.03 & 1.01 & 0.78 to 1.31 & \\
\hline \multirow[t]{5}{*}{ Marital status } & & & & & & 0.007 \\
\hline & Widowed/ & 252 & 31.75 & 1 & - & \\
\hline & Divorced/ & & & & & \\
\hline & Separated/Single & & & & & \\
\hline & Married & 896 & 43.64 & 1.55 & 1.12 to 2.15 & \\
\hline \multirow[t]{3}{*}{ Education } & & & & & & $<0.001$ \\
\hline & Lower education & 705 & 28.37 & 1 & - & \\
\hline & Higher education & 443 & 61.17 & 2.73 & 2.02 to 3.70 & \\
\hline \multirow{3}{*}{$\begin{array}{l}\text { Monthly income } \\
\text { (baht) }\end{array}$} & & & & & & $<0.001$ \\
\hline & $<15,000$ & 889 & 32.06 & 1 & - & \\
\hline & $\geq 15,000$ & 259 & 71.81 & 4.09 & 2.80 to 5.97 & \\
\hline \multirow[t]{3}{*}{ Occupation } & & & & & & $<0.001$ \\
\hline & $\begin{array}{l}\text { Unemployed/ } \\
\text { General hire/ } \\
\text { Agriculture }\end{array}$ & 868 & 32.72 & 1 & - & \\
\hline & $\begin{array}{l}\text { Government } \\
\text { servant/Trade }\end{array}$ & 280 & 66.79 & 2.86 & 2.03 to 4.04 & \\
\hline \multirow[t]{3}{*}{ Financial status } & & & & & & $<0.001$ \\
\hline & Inadequate & 348 & 24.71 & 1 & - & \\
\hline & adequate & 800 & 48.13 & 2.65 & 1.97 to 3.56 & \\
\hline \multirow[t]{3}{*}{ Smoking } & & & & & & 0.883 \\
\hline & Yes & 210 & 38.57 & 1 & - & \\
\hline & No & 938 & 41.58 & 1.02 & 0.74 to 1.42 & \\
\hline \multirow{3}{*}{$\begin{array}{l}\text { Alcohol } \\
\text { Consumption }\end{array}$} & & & & & & 0.732 \\
\hline & Yes & 279 & 45.52 & 1 & - & \\
\hline & No & 869 & 39.59 & 0.95 & 0.71 to 1.27 & \\
\hline \multirow[t]{3}{*}{ Physical activity } & & & & & & $<0.001$ \\
\hline & Inadequate & 779 & 33.25 & 1 & - & \\
\hline & Adequate & 369 & 57.45 & 2.25 & 1.71 to 2.95 & \\
\hline \multirow[t]{3}{*}{ Chronic diseases } & & & & & & 0.146 \\
\hline & Yes & 368 & 35.60 & 1 & - & \\
\hline & No & 780 & 43.59 & 1.24 & 0.93 to 1.65 & \\
\hline
\end{tabular}

The results indicated that high levels of CSC (adj. OR $=2.83$; 95\% CI: 2.01 to 3.97) and high levels of SSC (adj. OR = 2.64; $95 \%$ CI: 1.84 to 3.76 ) were associated with QOL. Other demographic and socioeconomic factors that were also associated with good QOL were being male (adj. OR $=1.71$; 95\%CI: 1.27 to 2.31 ), aged $<60$ years old (adj. OR $=2.70 ; 95 \% \mathrm{CI}: 1.72$ to 4.24 ), monthly income $\geq 15,000$ baht (adj. OR $=2.82 ; 95 \% \mathrm{CI}$ :
1.89 to 4.23 ), had adequate income (adj. OR $=2.14 ; 95 \% \mathrm{CI}$ : 1.54 to 2.97 ), lived in the town municipality (adj. $\mathrm{OR}=2.52$; 95\% CI: 1.32 to 4.80$)$. Others associated factors were had adequate physical activity (adj. $\mathrm{OR}=1.54 ; 95 \% \mathrm{CI}$ : 1.13 to 2.11 ) was associated with good QOL and had high levels of accessibility to health services $(\operatorname{adj} . \mathrm{OR}=1.53 ; 95 \% \mathrm{CI}$ : 1.10 to 2.12$)$. The results are shown in Table 4. 
Table 4. Multivariate analysis for factors associated with good quality of life (QOL) using GLMM (n $=1,148)$.

\begin{tabular}{|c|c|c|c|c|c|c|c|}
\hline \multicolumn{2}{|c|}{ Characteristics } & \multirow[t]{2}{*}{$\% \mathbf{N}$} & \multirow{2}{*}{$\begin{array}{c}\% \text { Good } \\
\text { QOL }\end{array}$} & \multirow[t]{2}{*}{ OR } & \multirow[t]{2}{*}{ Adj.OR } & \multirow[t]{2}{*}{$95 \% \mathrm{Cl}$} & \multirow{2}{*}{$\begin{array}{l}\text { P-value } \\
<0.001\end{array}$} \\
\hline Cognitive social & & & & & & & \\
\hline & Low/Moderate & 571 & 23.12 & 1 & 1 & - & \\
\hline & High & 577 & 58.75 & 5.30 & 2.83 & 2.01 to 3.97 & \\
\hline \multirow{3}{*}{$\begin{array}{l}\text { Structural social } \\
\text { capital }\end{array}$} & & & & & & & $<0.001$ \\
\hline & Low/Moderate & 733 & 29.33 & 1 & 1 & & \\
\hline & High & 415 & 61.69 & 4.83 & 2.64 & 1.84 to 3.76 & \\
\hline \multirow{3}{*}{$\begin{array}{l}\text { Accessibility to } \\
\text { health services }\end{array}$} & & & & & & & $<0.001$ \\
\hline & Low/Moderate & 433 & 20.55 & 1 & 1 & - & \\
\hline & High & 331 & 58.01 & 5.27 & 1.53 & 1.10 to 2.12 & \\
\hline \multirow[t]{3}{*}{ Residential area } & & & & & & & 0.005 \\
\hline & $\begin{array}{r}\text { Sub-district administrative } \\
\text { organization/Sub-district } \\
\text { municipality }\end{array}$ & 1,021 & 36.92 & 1 & 1 & - & \\
\hline & Town Municipality & 127 & 74.02 & 2.73 & 2.52 & 1.32 to 4.80 & \\
\hline \multirow[t]{3}{*}{ Gender } & & & & & & & $<0.001$ \\
\hline & Female & 696 & 38.36 & 1 & 1 & - & \\
\hline & Male & 452 & 45.13 & 1.45 & 1.71 & 1.27 to 2.31 & \\
\hline \multirow[t]{3}{*}{ Age (years) } & & & & & & & $<0.001$ \\
\hline & $\geq 60$ & 516 & 29.84 & 1 & 1 & - & \\
\hline & $<60$ & 632 & 50.16 & 2.37 & 2.70 & 1.72 to 4.24 & \\
\hline \multirow{3}{*}{$\begin{array}{l}\text { Monthly income } \\
\text { (baht) }\end{array}$} & & & & & & & $<0.001$ \\
\hline & $<15,000$ & 889 & 32.06 & 1 & 1 & - & \\
\hline & $\geq 15,000$ & 259 & 71.81 & 4.09 & 2.82 & 1.89 to 4.23 & \\
\hline \multirow[t]{3}{*}{ Financial status } & & & & & & & $<0.001$ \\
\hline & Inadequate & 348 & 24.71 & 1 & 1 & - & \\
\hline & Adequate & 800 & 48.13 & 2.65 & 2.14 & 1.54 to 2.97 & \\
\hline \multirow[t]{3}{*}{ Physical activity } & & & & & & & 0.007 \\
\hline & Inadequate & 779 & 33.25 & 1 & 1 & - & \\
\hline & Adequate & 369 & 57.45 & 2.25 & 1.54 & 1.13 to 2.11 & \\
\hline
\end{tabular}

* Adjusted for the effects of BMI, marital status, education, smoking, alcohol consumption, chronic disease, and occupation

Dataset 1. Social capital associated with quality of life among late adults and elderly population in the Northeast of Thailand

http://dx.doi.org/10.5256/f1000research.13954.d201414

Zip file containing raw data and word document with coding scheme for the dataset

\section{Discussion}

The main finding was discussed according to the objective of the study as follows: QOL measured by the WHOQOL - BREF. Majority of participants (58. 19\%) had fair level QOL, a followed by good level $(41.03 \%)$. This finding is similar to evidence indicated in Somrongthong $\mathrm{R}$ et $a l .{ }^{19}$ that the majority of 
participants $(58.19 \%)$ were at the "fair level". These two studies were similar in the way that they were conducted in the Northeast. However, they might share similar social economics factors. However, it was lower than study by Hongthong D et $a l^{20}$. Which found that most of the samples $(68.5 \%)$ had fair level of QOL. This study was conducted among rural settings which might contribute to rather lower level of QOL. About half of participants had high level of CSC and about one third had high level of SSC. It was confirmed by the results of the multivariable analysis that there was significantly association between SSC, CSC and QOL. The participants with high levels of SSC were 2.64 (95\% CI: 1.84-3.76) times higher odds of having good QOL. It is possibly because people who participate in political, sports and occupation association or groups may lead to high SSC in term of scope and intenseness of links both within and outside the community. The more social connectedness, political participation, civic engagement they had the more satisfaction with life and relationships were found.

Those with high level of CSC had 2.83 (95\%CI: 2.01 to 3.97) times higher QOL than those with lower CSC. A possible explanation for this finding could be the CSC indicates capability of people to obtain various resources of social particular from their family, community, society, and health sectors ${ }^{21}$. People with high CSC are more likely to enthusiastic to find out for information, spiritual contribute networks. They tend to perform with social norms and peer control, could establish trust and be alive with others ${ }^{22-26}$.

Concerning accessibility to health services, this study indicated that about one-third of participants had chronic diseases within the past year $(32.06 \%)$. The participants who had better access to health services were $1.53 \% \quad(95 \% \mathrm{CI}$ : 1.10-2.12) higher odds of having high QOL. Access health services have intense effect on every aspect of quality of life. Access to quality health services is significant for promoting health, preventing disease, reducing disability and mortality which is a component of QOL.

Residential area also influenced people's QOL. In residential area, the influence of different lifestyles and stages of life have to be taken into account. The findings of this studies indicated that participant who lived in the town municipality had high QOL. This may be because the town municipality has good standard of living, good environmental health, better access to goods and health services, and better economic conditions ${ }^{27}$.

Our result noted that gender was associated with QOL, of which similar with the evidence found in other studies that QOL was significantly varied with gender ${ }^{28,29}$. This study has shown that females had significantly poorer QOL when compared with males. Globally, some studied also indicated that females had lower QOL than males ${ }^{30-32}$. It was found that $60.72 \%$ and $61.41 \%$ of females who reported having lower education and monthly income, respectively than males, of had lower QOL. In some studies, higher education and income participants usually had higher QOL scores ${ }^{30,33}$. It is common in some countries that females were less privileged with inaccessibility to information and education resulting in disadvantages for employment, economic status and social position. Even though, women lived longer than men, they were more likely to suffer ill health than $\operatorname{men}^{34}$.

The QOL was significantly lower among participant among older persons ${ }^{30}$. Moreover, with increasing age, the QOL were decreasing, which was consistent with previous studies showed that elderly individuals suffering from poor QOL ${ }^{35}$. This study provides further evidence the older the individual, the QOL decreases. As the age advances, the health related problems become more common to a person. Gradually people are more weakening and finally confined to their own houses. Loneliness is commonly present. As age increases, the chance of losing spouse becomes more, loneliness increases to a much greater extent. Therefore, overall the physical and psychological QOL becomes poorer with the advancement of age. Beside this, the social interaction decreases with increased age. So, the social relationship domain of QOL becomes worse ${ }^{36}$.

This study also indicated that monthly income was associated with QOL. Those who had lower monthly income had lower level of $\mathrm{QOL}^{33}$. A possible explanation for this finding could be that poverty causes poor health status ${ }^{30}$. Different in employment status and occupation resulted in different income. Therefore, they would have different social security and health insurance which have influence on their health and wellbeing ${ }^{32}$. The increase in per capita income indicates better socio-economic status $^{36}$. An increase in per capita monthly income significantly improved the QOL scores.

A profound association was found between having adequate income and QOL. Participants who were poor with inadequate income faced various problems. Having sufficient income is important to QOL It help covering, meeting the basic needs of life. In addition it also increases the opportunity to participate in social activities to enjoy hobbies, holidays and luxuries ${ }^{37}$.

Physical activity also had high influence on QOL and has been profoundly discussed in the literature ${ }^{38}$. In this study active physical activity was associated with QOL. For instance, good QOL was found 1.54 times more among participants who had adequate practiced physical activity.

This study has indicated both the QOL and social capital situations and their association which are highly useful to planning for relevant actions. However, it is important to aware that a limitation of cross-sectional study is that because the exposure and outcome are simultaneously assessed, no causal relationship can be identified. It is important suggestion for a further study 
which could identify the causal relationship using other study designs such as a cohort study.

\section{Conclusion}

This community based cross sectional found that less than half of late adults and elderly had good QOL and high level of SSC. About half had high level of CSC. Both CSC and SSC had influence on QOL as well as gender, age, monthly income, financial status, physical activity, residential area, and accessibility to health services. Relevant sectors could use the evident from this study to develop proactive strategies and measures to improve health and reducing inequalities in health through healthy public policy and strengthen community actions to improve their social capital, access to health care and socioeconomic status.

\section{Data availability}

Dataset 1: Social capital associated with quality of life among late adults and elderly population in the Northeast of Thailand.
Zip file containing raw data and word document with coding scheme for the dataset. 10.5256/f1000research.13954.d201414 ${ }^{39}$

\section{Competing interests}

No competing interests were disclosed.

\section{Grant information}

This research was financially supported by the Research and Training Center for Enhancing Quality of Life for Working Age People, Khon Kaen University, Thailand.

The funders had no role in study design, data collection and analysis, decision to publish, or preparation of the manuscript.

\section{Acknowledgements}

The authors would like to express sincere thanks and appreciation to all participants who participated in this study.

\section{Supplementary material}

Supplementary File 1 - Questionnaire used in the study.

Click here to access the data.

1. Skevington SM, Lotfy M, O'Connell KA: The World Health Organization's WHOQOL-BREF quality of life assessment: psychometric properties and results of the international field trial. A report from the WHOQOL group. Qual Life Res. 2004; 13(2): 299-310.

PubMed Abstract | Publisher Full Text

2. WHOQOL Group: Study protocol for the World Health Organization project to develop a Quality of Life assessment instrument (WHOQOL). Qual Life Res. 1993; 2(2): 153-9.

PubMed Abstract | Publisher Full Text

3. Bonomi AE, Patrick DL, Bushnell DM, et al.: Validation of the United States version of the World Health Organization Quality of Life (WHOQOL) instrument. J Clin Epidemiol. 2000; 53(1): 1-12. PubMed Abstract | Publisher Full Text

4. Hsieh $\mathrm{CH}$, editor: A concept analysis of social capital within a health context. Nurs Forum. Wiley Online Library. 2008; 43(3): 151-9. PubMed Abstract | Publisher Full Text

5. Murayama H, Fujiwara $\mathrm{Y}$, Kawachi I: Social capital and health: a review of prospective multilevel studies. J Epidemiol. 2012; 22(3): 179-87. PubMed Abstract | Publisher Full Text | Free Full Text

6. Story WT: Social capital and health in the least developed countries: a critica review of the literature and implications for a future research agenda. Glob Public Health. 2013; 8(9): 983-99.

PubMed Abstract | Publisher Full Text | Free Full Text

7. Fujisawa $\mathrm{Y}, \mathrm{Hamano} \mathrm{T}$, Takegawa S: Social capital and perceived health in Japan: an ecological and multilevel analysis. Soc Sci Med. 2009; 69(4): 500-5. PubMed Abstract | Publisher Full Text

8. Nyqvist F, Forsman AK, Giuntoli G, et al.: Social capital as a resource for mental well-being in older people: a systematic review. Aging Ment Health. 2013; 17(4) 394-410.

PubMed Abstract | Publisher Full Text

9. Karimzadeh M: Impact of social capital on quality of life: Evidence from India. IJEPT. 2013; 3(4): 264-71.

Reference Source

10. Bourdieu P, Wacquant LJ: An invitation to reflexive sociology. University of
Chicago press; 1992

Reference Source

11. Maliski SL, Connor SE, Oduro C et al: Access to health care and quality of life for underserved men with prostate cancer. Semin Oncol Nurs. 2011; 27(4): 267-77.

PubMed Abstract | Publisher Full Text

12. Cohen N, Galea S: Population mental health: Evidence, policy, and public health practice. T\&F. 2011. Reference Source

13. Hsieh FY, Bloch DA, Larsen MD: A simple method of sample size calculation for linear and logistic regression. Stat Med. 1998; 17(14): 1623-34. PubMed Abstract | Publisher Full Text

14. Mahatnirundkul S: Comparison of the WHOQOL-100 and the WHOQOL-BREF (26 items). J Ment Health Thai. 1998; 5: 4-15. Reference Source

15. Taboonpong S, Suttharangsee W, Chailangka P: Evaluating psychometric properties of WHO quality of life questionnaire in Thai elderly. $J$ Gerontol Geriatric Med. 2001; 2: 6-12.

16. Bain K, Hicks N: Building social capital and reaching out to excluded groups: the challenge of partnerships. World Bank. 1998.

17. Penchansky R, Thomas JW: The concept of access: definition and relationship to consumer satisfaction. Med Care. 1981; 19(2): 127-40. PubMed Abstract

18. Hubbard AE, Ahern J, Fleischer NL, et al:: To GEE or not to GEE: comparing population average and mixed models for estimating the associations between neighborhood risk factors and health. Epidemiology. 2010; 21(4): 467-74.

PubMed Abstract | Publisher Full Text

19. Somrongthon R, Wongchalee S, Yodmai K, et al:: Quality of Life and health status among Thai elderly after economic crisi, Khon Kanen province, Thailand. Eur J Sci Res. 2013; 112(3): 314-24.

20. Hongthong D, Somrongthong R, Ward P: Factors Influencing the Quality of Life (Qol) Among Thai Older People in a Rural Area of Thailand. Iran J Public Health. 
2015; 44(4): 479-85.

PubMed Abstract | Free Full Text

21. Hu F, Niu L, Chen R, et al:: The association between social capital and quality of life among type 2 diabetes patients in Anhui province, China: a crosssectional study. BMC public health. 2015; 15(1): 786.

PubMed Abstract | Publisher Full Text | Free Full Text

22. Lucumi DI, Gomez LF, Brownson RC, et al: Social capital, socioeconomic status, and health-related quality of life among older adults in Bogotá (Colombia). J Aging Health. 2015; 27(4): 730-50.

PubMed Abstract | Publisher Full Text | Free Full Text

23. Deshmukh PR, Dongre AR, Rajendran K, et al:: Role of social, cultural and economic capitals in perceived quality of life among old age people in kerala, india. Indian J Palliat Care. 2015; 21(1): 39-44.

PubMed Abstract | Publisher Full Text | Free Full Text

24. Kim D, Kawachi I: U.S. state-level social capital and health-related quality of life: multilevel evidence of main, mediating, and modifying effects. Ann Epidemiol. 2007; 17(4): 258-69.

PubMed Abstract | Publisher Full Text

25. Rimaz S, Mohammad K, Dastoorpoor M, et al:: Investigation of relationship between social capital and quality of life in multiple sclerosis patients. Glob Health Sci. 2014; 6(6): 261-72.

PubMed Abstract | Publisher Full Text | Free Full Text

26. Kleinman A, Wang WZ, Li SC, et al.: The social course of epilepsy: chronic illness as social experience in interior China. Soc Sci Med. 1995; 40(10): 1319-30.

PubMed Abstract | Publisher Full Text

27. Sahin NP, Fasli M, Vehbi BO: An assessment of quality of life in residential environment: case of Selimiye Quarter in Walled City of Nicosia, north cyprus. 2007; 23: 2012.

Reference Source

28. Burström K, Johannesson M, Diderichsen F: Health-related quality of life by disease and socio-economic group in the general population in Sweden. Health Policy. 2001; 55(1): 51-69.

PubMed Abstract | Publisher Full Text

29. Scalone L, Cortesi PA, Ciampichini R, et al:: Health related quality of life norm data of the Italian general population: results using the EQ-5D-3L and
EQ-5D-5L instruments. Epidemiol Biostat Public Health. 2015; 12(3).

Reference Source

30. Shiroiwa $T$, Fukuda $T$, Ikeda $S$, et al: Japanese population norms for preferencebased measures: EQ-5D-3L, EQ-5D-5L, and SF-6D. Qual Life Res. 2016; 25(3): 707-19.

PubMed Abstract | Publisher Full Text | Free Full Text

31. Ferreira LN, Ferreira PL, Pereira LN, et al.: EQ-5D Portuguese population norms. Qual Life Res. 2014; 23(2): 425-30. PubMed Abstract | Publisher Full Text

32. Sun S, Chen J, Johannesson M, et al.: Population health status in China: EQ5D results, by age, sex and socio-economic status, from the National Health Services Survey 2008. Qual Life Res. 2011; 20(3): 309-20. PubMed Abstract | Publisher Full Text | Free Full Text

33. Luo N, Johnson JA, Shaw JW, et al:: Self-reported health status of the general adult U.S. population as assessed by the EQ-5D and Health Utilities Index. Med Care. 2005; 43(11): 1078-86.

PubMed Abstract | Publisher Full Text

34. Annandale E, Hunt $\mathrm{K}$ : Gender inequalities in health: research at the crossroads. 2000.

Reference Source

35. Tajvar M, Arab M, Montazeri A: Determinants of health-related quality of life in elderly in Tehran, Iran. BMC Public Health. 2008; 8: 323 PublMed Abstract | Publisher Full Text | Free Full Text

36. Datta D, Datta PP, Majumdar KK: Association of quality of life of urban elderly with socio-demographic factors. IJMEDPH. 2015; 5(4): 274-278. Publisher Full Text

37. Bowling A: Ageing well: Quality of life in old age: McGraw-Hill Education (UK). 2005.

Reference Source

38. Sampaio PY, Ito E: Activities with higher influence on quality of life in older adults in Japan. Occup Ther Int. 2013; 20(1): 1-10. PubMed Abstract | Publisher Full Text

39. Prachuntasen K, Laohasiriwong W, Luenam A: Dataset 1 in: Social Capital Associated with Quality of Life among Late Adults and Elderly Population in the Northeast of Thailand. F1000Research. 2018.

Data Source 


\section{Open Peer Review}

\section{Current Peer Review Status: ? ?}

\section{Version 1}

Reviewer Report 16 July 2019

https://doi.org/10.5256/f1000research.15168.r37414

(C) 2019 Lam A. This is an open access peer review report distributed under the terms of the Creative Commons Attribution License, which permits unrestricted use, distribution, and reproduction in any medium, provided the original work is properly cited.

\section{Agnes Iok Fong Lam}

Department of Communication, Faculty of Social Sciences, University of Macau, Macau, China

This paper shows the correlation between good quality of life and social capital and some factors like gender, income, and accessibility to health services. It is an analysis of the situation of Northeast of Thailand that can inform policy needs for the community. However, it is worth to point out the following:

The "Introduction" is not comprehensive enough to understand the context, especially for readers outside Thailand. Census information on the population (the Northeast of Thailand, paragraph 2) should be more concise and specific for the denotation like "It is the poorest region in the country." Also, it would be much more convincing if studies are provided to support statements like "many of Northeastern migrate to work in other regions and overseas. Many of them usually leave family members to include the elderly at home." For status like "there have been limited studies on SC among the Northeasterners and its association with QOL," it is expected that to quote a few (like one or two) of these studies and pointed out their relevance to the topic.

The conclusion is sound, and the figures are clearly stated and shown. However, discussion into the context will be necessary - for example, demographic statistics (Table 1. Characteristics of participants in the Northeast of Thailand) shows that the percentage of employed participants that work as "Government servant" is very high, $13.85 \%$ out of the total population, it is more than onequarter of the employed population. In Table 4 (Multivariate analysis for factors associated with good quality of life (QOL) using GLMMT), employment status was not shown as a factor associated with good quality of life. Since "Government servant" is the second largest industry among the survey population, just after agriculture, it would be worth to add some observation over the employment issues even the cross-sectional data analysis shows that employment stats is not significant. Demographic data shows that the studied area has a unique market structure, and the paper needs to elaborate if the result could be applied to the rest of Thailand or some other middle-income developing 's countries.

Is the work clearly and accurately presented and does it cite the current literature? 
Partly

Is the study design appropriate and is the work technically sound?

Yes

Are sufficient details of methods and analysis provided to allow replication by others? Yes

If applicable, is the statistical analysis and its interpretation appropriate?

Yes

Are all the source data underlying the results available to ensure full reproducibility? Partly

Are the conclusions drawn adequately supported by the results?

Partly

Competing Interests: No competing interests were disclosed.

Reviewer Expertise: communication, media, public policy

I confirm that I have read this submission and believe that I have an appropriate level of expertise to confirm that it is of an acceptable scientific standard, however I have significant reservations, as outlined above.

Reviewer Report 08 May 2018

https://doi.org/10.5256/f1000research.15168.r33481

(C) 2018 Najafi F. This is an open access peer review report distributed under the terms of the Creative Commons Attribution License, which permits unrestricted use, distribution, and reproduction in any medium, provided the original work is properly cited.

\section{Farid Najafi}

Research Center for Environmental Determinants of Health, Kermanshah University of Medical Sciences, Kermanshah, Iran

This is a cross-study on association between social capital and quality of life in Thailand. The justification of study has been provided in "Introduction". However, there are many studies on such associations that authors can cite some of them in Introduction.

While the details of multistage random sampling have been provided, justification for calculated number of participants (second paragraph under the subheading of "study participants") has been written in a wrong way and need to be re-written.

We did not know "Conbach alpha". It might be Cronbach's alpha. Justification for classification of 
SC as a dichotomized variable is not correct and sufficient. This is true for accessibility to health service.

The manuscript need severe English language editing service.

The presentation of Tables is understandable and appropriate.

Is the work clearly and accurately presented and does it cite the current literature? Partly

Is the study design appropriate and is the work technically sound? Partly

Are sufficient details of methods and analysis provided to allow replication by others? Partly

If applicable, is the statistical analysis and its interpretation appropriate? Partly

Are all the source data underlying the results available to ensure full reproducibility? No

Are the conclusions drawn adequately supported by the results? Yes

Competing Interests: No competing interests were disclosed.

I confirm that I have read this submission and believe that I have an appropriate level of expertise to confirm that it is of an acceptable scientific standard, however I have significant reservations, as outlined above. 
The benefits of publishing with F1000Research:

- Your article is published within days, with no editorial bias

- You can publish traditional articles, null/negative results, case reports, data notes and more

- The peer review process is transparent and collaborative

- Your article is indexed in PubMed after passing peer review

- Dedicated customer support at every stage

For pre-submission enquiries, contact research@f1000.com 